\title{
THE
}

2018

\section{Methods for Evaluating the Value of Intangible Assets}

Jeffrey E. Jarrett

University of Rhode Island, jejarrett133@outlook.com

Follow this and additional works at: https://digitalcommons.uri.edu/cba_facpubs

The University of Rhode Island Faculty have made this article openly available.

Please let us know how Open Access to this research benefits you.

This is a pre-publication author manuscript of the final, published article.

Terms of Use

This article is made available under the terms and conditions applicable towards Open Access

Policy Articles, as set forth in our Terms of Use.

\section{Citation/Publisher Attribution}

Jarrett, J. (in press). Methods for Evaluating the Value of Intangible Assets. IJBDA.

Available at: https://www.inderscience.com/info/ingeneral/forthcoming.php?jcode=ijbda

This Article is brought to you for free and open access by the College of Business at DigitalCommons@URI. It has been accepted for inclusion in College of Business Faculty Publications by an authorized administrator of DigitalCommons@URI.For more information, please contact digitalcommons-group@uri.edu. 


\title{
Methods for evaluating the value of intangible assets
}

\author{
Jeffrey E. Jarrett \\ College of Business, \\ University of Rhode Island, \\ Data Analytics Ballentine Hall, \\ Kingston, RI 02881, USA \\ Email: jejarrett133@gmail.com
}

\begin{abstract}
Intangible assets, intellectual property, estimating cash flow, and rates of return are concerned with the inaccuracy and biases involved in predicting earnings and rates of return. Financial reporting is the major source of data utilised by economic forecasts, accountants, and financial managers to predict future cash flow and earnings (whether per share or in aggregate). However, the records and studies of analyst forecasts have produced often dismal performance. Previous studies focused on historical analysis of past earnings forecast methodology or on generating evidence that accrual accounting justifies better forecasting performance. Objections to these areas of study come in several forms. Justifying accrual accounting owing to poor performance of earnings forecasts may not be appropriate. Also, the financial reporting of intangible assets is often misleading or is not reported at all. Economic forecasters know that if the reporting of assets that greatly affect cash flow and, in turn, earnings forecasters is a serious source of error in forecasting. Using sophisticated models for forecasting with error adjustments may improve forecast accuracy as shown previously. In turn, the absence of studying intangible assets will still produce inaccurate results.
\end{abstract}

Keywords: intangible assets; intellectual property; estimation theory; mergers and acquisitions; M\&A; earnings forecasts.

Reference to this paper should be made as follows: Jarrett, J.E. (2019) 'Methods for evaluating the value of intangible assets', Int. J. Business and Data Analytics, Vol. 1, No. 2, pp.145-155.

Biographical notes: Jeffrey E. Jarrett is a former Chairperson of the Department of Management Science and IS and Professor of Finance at the University of Rhode Island. He holds diplomas from the University of Michigan and New York University. He has published extensively in The Accounting Review, Decision Sciences, Journal of Business Finance and Accounting, Journal of Accounting Research, Journal of Finance, Management Science, Technometrics, International Journal of Forecasting, Journal of Applied Statistics, OMEGA, etc. He is the author of a number of books on such topics as statistical analysis for decision-analytics and business forecasting. 


\section{Introduction}

Dechow (1994) and Dechow and Strand (2004) postulated that the use of accrual-based accounting methods increased the capability of accounting-based forecasts to improve the ability to measure firm performance reflected in returns to equity investments. The argument was that cash flow accuracy is expected to suffer from matching, realisation, and other timing problems concerning the timing of the recognition of costs and revenues. Accuracy of financial reports was studied by many including Brandon and Jarrett (1974), Jarrett (1983, 1992), and Jarrett and Khumawala (1987). They compared methods of forecasting accounting earnings seeking to learn how forecast models can be compared and possibly improved to produce more-accurate results. Questions posed included sources of accuracy, but accrual accounting was not considered the most important source of inaccurate results. However, no one established a theoretical link between sources of inaccuracy and the matching principle and the accuracy of financial analysts' forecasts although many studied the problem (Brandon and Jarrett, 1974; Clement, 1999; Gu and Wu, 2003; Ramnath et al., 2008; Groysberg et al., 2011). Financial reports containing these forecasts of cash flow and rates of return are subject to fluctuations in the interpretation of timing principles utilised by accountants. However, $\mathrm{Gu}$ and Wang (2005) brought up the possibility of another source of inaccuracy in the forecast of rates of return: cash flow and earnings.

There is a substantial relation between analysts' forecasts and the magnitude and value of intangible assets. Intangible assets were not considered in the forecasting method discussed by the researchers in their many and detailed studies. The value of intangible assets produces a great source of error if they are not considered in the forecasting methods utilised by analysts in the production of cash flow and rates of return earning per share forecasts. When adjustments for intangible assets are included in the analyst's forecasts, Gu and Wang (2005, p.673) stated that "the rise of intangible assets in size and contribution to corporate growth over the last two decades poses an interesting dilemma for analysts. Most intangible assets are not recognized in financial statement, and current accounting rules do not require firms to report separate measures for intangibles." Intangibles include trademarks, brand names, patents, and similar properties that have value but are generally not listed on financial reports of firms. Many of these items are technology-based and are very important in financial decisions such as in mergers and acquisitions (M\&A). They are intricate decisions in the growth of firms and therefore are shown to be related in the statistical sense to the overall estimates made by accounting and analysts.

In another study concerning forecasts, Lambert et al. (2015) found that the association between earnings per share (EPS) forecast, growth rates forecast error, and measures of technological conditions in the firm's industry. They found that as the forecast horizon increases, the technological conditions and current EPS are statistically associated with analysts' forecasts. Long horizon creates the conditions for within one to conclude that interactions between technological conditions and current EPS are associated with analysts' EPS and growth forecasts. This conclusion aligns itself with Jung et al. (2012), who suggested that analysts' growth forecasts effect efforts to evaluate analysts' forecasts may produce optimistically biased long-term forecasts. Because intangible assets that are often technology-based take up more of the balance sheet of many firms, it is likely that 
analysts' forecasts may produce less-accurate predictions of earnings, cash flow, and rate of return. Balance sheets usually have little or no involvement with the value of intangibles, although there are some practices by accounting that are still used.

\section{The literature on intellectual property and traditional accounting methodology}

As noted by Brief (1977), Brief and Owen (1968, 1969, 1970), Jarrett (1971, 1974, 1983, 2016), Roberts and Roberts (1970), Bierman (1971), Barnea and Sadan (1974), Pappas (1977), and Beneish et al. (2013), the timing of recognition of revenue for intellectual property (IP; see WTO, 2016) in financial statements of ten are not featured in M\&A activity. The Financial Accounting Standards Board (FASB) provides for such activities; however, the FASB is often ignored because of their evasiveness or because they are not fully informational in their normally structured rules. By contrast, Jin et al. (2015) utilised estimation theory in building rules for international reports employing the matching principle. Recognising future performance is a goal of matching and timing but is unrelated to recognising cash flow and similar items in the historical performance of a firm. Non-profit entities often do not use accrual rules at all because the goal of these are related to achieving high rates of return. Often, intellectual property rights (IPR) for non-profits would differ from the same item for profit-maximising entities because the goal of seeking high rates of return does not enter the strategic planning process for non-profits. The purpose here is to consider IP as intangible assets and as a product of intellect that law protects from unauthorised use by those not responsible for the IPR. Hence, IPR are characterised as the protection of distinguished signs such as trademarks for goods and services, patents, and other similar items that are under protection from unauthorised use (WTO, 2016). This includes art, music, and creations by authors including the authorship of computer software and similar items such as discoveries, inventions, phrases, symbols, and design. Obviously, a writer and conductor of music such as Leonard Bernstein, Daniel Barenboim, and James Levine would have created IP that differ greatly from physicists such as Lise Meitner, Niels Bohr, and Albert Einstein. [To understand the gravity of ignoring or improperly valuing IPR, see Hagendorff et al. (2012) and Jarrett (2017a, 2017b).] This result debated previously (Brief and Owen, 1969; Pappas, 1977; Brief, 1977; Matolcsy and Wyatt, 2006) indicated that including earnings risk may not fully reflect all risk in estimating earnings, but at least, it reflects that part of risk from the variation in earnings.

\section{Contemporary accounting methods}

Presently, accounting suggests two methods to determine the value of IPR to produce better estimates of from accounting analysts' forecasts. The convention of the 'lower of cost or market' is based on the rule of conservatism in valuing assets to anticipate future losses instead of future gains. The policy tends to understate rather than overstate the value of net assets and could therefore lead to an understatement of income, cash flow, earnings, and rates of return. The purpose of this study and its conclusive result is to 
neither understate nor overstate cash flow so as to produce a rate of return on cash flow that is commensurate with the goal producing accurate prediction of cash flow and its rate of return for financial and decision-making purposes. Stated differently, the purpose is not to violate accounting policy but to ensure the M\&A that cash flow is estimated properly. Traditionally, accounting writes policy about intangible assets as a residual. By residual, they mean a buyer is ready to value a firm in excess of the value of the tangible assets. This value is often referred as goodwill (White et al., 1994), which is an imperfect method. This notion of goodwill is estimated as a residual value. The valuation of intangible property is imperfect because it considers part of the solution of a bargaining process. In this case, the buyer and seller may have different market power that greatly affects the residual of the bargaining process and produces an imperfect or biased estimate of the value of the intangible assets. One may examine the case of the sale of Superman by struggling comic artists to a much larger corporate power who could market the character to comic books, television, and the film industry. The nearly destitute conditions of the original artists who created the intangible product could never cope with the business and marketing (power) of those who purchased the name Superman. Thus, goodwill tends to be a vague valuation system that justifies the bringing of data analysis and science into the valuation process.

Another solution suggested during the M\&A process is to simply list the patents, trademarks, brands, and similar items of IP in the financial reporting of the firm. Following this initiative and suggestion of the Accounting Principles Board provides little aid concerning the economic value of IPR and products for a firm during the M\&A events (Hagendorff et al., 2012). In the final step of the problem, the evaluation may conclude influence relating to the biases of the reading of the financial reports. Such biases of IP occurred often with the works of Meitner, Einstein, and Bohr. Whereas, at least Einstein and Bohr received Nobel Prizes that did have wealth, but Meitner, perhaps due to her gender and religious preference, never received the award the others were given. For the three conductors and composers of music, there was no economic award from the Nobel Prize committees. Accountants forecast the overall rate of return for a firm but do not ignore the convention of conservatism. Accounting practice values the IPR for a firm each year for each and every IP right under consideration. The principle of goodwill is not to be used during M\&A activity to account for the value of IPR. IP may induce greater asset values, but it also affects the rate of return on cash flow because the denominator of the rate of return will change.

\section{Estimating cash flow attributable to intangible assets}

Estimation theory in accounting is consistent with traditional accounting and assumes the objective by becoming part of the foundation of modern account (Brief and Owen, 1968). Estimation methods are cost-based allocation procedures and are utilised to express the accounting rate of return used to predict the value of intangible assets and the cash flow associated with rates of return on cash flow. Based on the notion and observable evidence, there is a relation between the increase in the value intangible assets and the cash flow associated with a firm's assets. Because a purpose of accounting is to provide 
information for predicting parameters - that is, the rate of return for a decision model - a method for relating information is estimation theory (see Gordon and Halpern, 1974; Jarrett, 1978).

Without repeating the general model developed by Brief and Owen (1968) and implemented in another allocation model by Jarrett (1978), we may observe the set of allocation methods, $p_{i}$ in which the allocation system is as follows:

$$
p_{i}=\frac{X_{i}}{C}-\frac{W_{i}}{\sum W_{i}}\left[\frac{\sum W_{i}-C}{C}\right]
$$

One utilises

$c \quad$ joint cost

$P_{i} \quad$ proportion of $\mathrm{C}$ allocated to the ith joint product, activity, division, etc.

$X_{i} \quad$ a numerical characteristics or assigned to the ith product, division, etc.

$W_{i} \quad$ a numerical characteristic chosen to standardise the differences, $\left(X_{i}-p_{i} C\right)^{2}$.

The actual cost assigned to the $i^{\text {th }}$ product or division is the product or division $p_{i}$ and $C$. We can further show that the solution to $P_{i} C$ is:

$$
p_{i} C=X_{i}-\frac{W_{i}}{\sum W_{i}}\left[\frac{\sum W_{i}-C}{C}\right]
$$

We can now define the fraction:

$$
\frac{X_{i}-p_{i} C}{W_{i}}
$$

As a constant equal to $r_{i}$, the rate of return for product asset $i$. By substitution of (1) in (2), we can show:

$$
r_{i}=\frac{X_{i}-p_{i} C}{W_{i}}=\frac{X_{i}-X_{i}-\frac{W_{i}}{\sum W_{i}}\left(\sum X_{i}-C\right)}{W_{i}}
$$

which reduces to:

$$
r_{i}=\frac{\sum X_{i}-C}{\sum W_{i}}
$$

We should note at this point that the fraction (5) is the rate of return on cash flow of the firm denoted by $k$. Previously, Brief and Owen (1968, p.195) indicated that it is difficult to interpret the equality (6) unless the characteristic chosen is a measure of value or is assumed to be highly correlated with such a measure. However, when measures of value 
are chosen for $X_{i}$ and $W_{i}$, profits assigned are related to value. Further, methods that establish a value equality among assets appear more reasonable than those that do not.

Similarly, methods for accounting for depreciation are essentially the same as those used to apportion joint costs to carious assets of the firm. These methods result from specifying $W_{i}=X_{i}$. Methods of allocating joint asset costs to individual assets divisions are thus similar to allocating depreciation on accruals. Additionally, this is true whenever profits are proportional to the value produced in each asset or portion of a firm.

At this point, we note that whenever $W_{i}=X_{i}$, the problem of allocating costs and revenues to a product or segment of a firm is further compounded if we introduce uncertainty into the problem. Uncertainty enters the process whenever we are uncertain as to precisely how much of the joint expenses or revenues must be allocated to an individual asset. Introducing uncertainty into the process of selecting an allocation scheme transforms our problem into one of statistical estimation theory. We now employ Brief and Owen (1968) to define $g_{i t}$.

Let $g_{i t}$ be the rate of growth in cash flow from firm $j$ in period $d, g_{i t}$ be the rate of growth in cash flow for asset $i$ of firm $j$ in period $t, g_{m t}$ and be the rate of growth of a diversified portfolio of firms in period $t$. By regressing $g_{j t}$ on $g_{m t}$ over a given time period, we obtain

$$
g_{j t}=\hat{\alpha}_{j}+\hat{C}_{j} g_{m t}
$$

We estimate the growth in income attributable to a division by allocating the firm's joint expenses among the divisions. Thus, equation (1) could be rewritten for a division as follows:

$$
g_{i t}=\hat{\alpha}_{i j}+\hat{C}_{i} g_{m t}
$$

In (7), $\hat{C}_{i}$ is the estimator of the covariance-variance ratio of systematic risk of division $i$ of firm $j$ based on the rate of growth in the income attributable to the asset.

The estimators of the systematic risk, $\hat{C}_{j}$ and $\hat{C}_{i}$, from equations (6) and (7) are hypothesised by Gordon and Halpern to be highly correlated with the measure of systematic risk from Markowitz-Sharpe capital asset pricing model (CAPM) (usually referred to as $\beta$ ). To estimate the realised rate of growth $g_{j t}$ for firm $j$ in period $t$, we let:

$Y_{j t} \quad$ earnings before interest and taxes during $t$

$I_{t} \quad$ interest payment on debt outstanding during $t$.

For simplicity, we assume that the interest rate and the outstanding debt remain the same from period to period. Hence, $I_{t}$ is the same in all periods, the rate of growth in earnings on common during $t$ is:

$$
g_{i t}=\frac{\hat{Y}_{j t}-\hat{Y}_{j t-1}}{Y_{j t-1}-I_{t}}
$$

Earnings $Y_{j t}$ for a firm is simply defined as the residual of revenues minus expenses. For a firm, this is expressed as follows: 


$$
Y_{j t}=\sum_{i=1}^{n} X_{i}-C
$$

where $X_{i}=$ net cash flows (sales less variable, i.e., other direct costs) for an estimation theory to solve the problem of allocating joint costs or revenues to an asset.

Let us now solve the problem of allocating joint costs (and revenues) in the face of uncertainty when $W_{i}=X_{i}$. The proportion of joint values $C$ allocated to asset $t$ is given by the following allocation scheme:

$$
p_{i}=\frac{E^{-1}\left(X_{i}\right)}{\sum_{i=1}^{n} E^{-1}\left(X_{i}\right)} \frac{M_{i}}{1+b_{1}^{2}}\left[\frac{1}{\sum_{i=1}^{n}\left(M_{i} /\left(1+b_{1}^{2}\right)\right)}\right]
$$

where $M_{i}=$ expected cash flow for asset $i$, that is, the mean $X_{i}$ for an asset and $b_{i}=\left(S_{i} / M_{i}\right)$ is the coefficient of variation of $X_{i}$, and $S_{i}$ is the standard deviation of $X_{i}$. The above equation assumes that the coefficient of variation is the only relevant measure of variability for the distribution of cash flow.

Equation (10) indicates that if we are uncertain as to how much cash flow is attributable to each asset, the size of this uncertainty will affect the size of the allocation, $p_{i}$. When uncertainty is greater, that division, product, or segment will be allocated less of the joint costs. The result is consistent with the goal of conservatism whereby accountants allocate less to an account when we are less certain about how much to allocate. In (10), we see that uncertainty is introduced by the coefficient of variation, $b_{i}$. As $b_{i}$ increases in value, $p_{i}$ decreases, which is consistent with how accountants operate.

\section{Estimation of aggregate cash flow}

The last step in estimating cash flow to find and develop the contribution of intangible assets to forecast analysts' earnings is to implement the estimate of an intangible asset's cash flow and find it's total or aggregate. We define:

$$
\left(Y_{i t, e s t}\right)=X_{i}-p_{i} C
$$

Observe that larger values for $p_{i}$ will underestimate income and smaller values overestimate income. When uncertainty is larger - that is, $b_{i}$ is large $-p_{i}$ is small and income is larger. Obviously, when uncertainly is small, the reverse is true. Small values for $Y_{i t, e s t}[t=1,2,3]$ increases the realised gate of growth, $g_{i t, e s t}$, for intangible asset $I$ in period $t$. The reason for this response is that the numerator of (7A) remains the same as the denominator (7A) which becomes smaller. An upward bias in $g_{i t \text {,est }}$, the realised rate of growth, naturally results in an upward bias in the rate of return for an individual asset. Thus, the use of accounting numbers for cash flow, incomes, and others to estimate and predict the forecast of a rate of return becomes a very risky methodology, Underestimation of the cash flow attributable to estimating the value of intangible assets usually results in error in estimating the rate of return because the rate of growth is not predicted precisely. 


\section{Example of estimating the value of intellectual property rights and other intangible assets}

The three examples found in Tables 1-3 show the variation when one variable in the analysis changes. Table 1 calculates the dollar value of intangible or IPR when $S(X)$ changes. As the variation increases in value, the IPR \$ will decrease in value. This is expected from other sources of decision modelling in financial accounting applications including Thornton (2013), Kimouche and Rouabbi (2016), and many others discussed in these studies.

Table 1 I (interest) monetary equivalents

\begin{tabular}{lccccc}
\hline$E(X)$ & $S(X)$ & Cost of debt & $Z \beta$ & Probability [normal $(C D F)]$ & IPR \$ \\
\hline 4,500 & 400 & 3,000 & 3.75 & .999 & 4,495 \\
4,500 & 500 & 3,000 & 3.00 & .9987 & 4,494 \\
4,500 & 600 & 3,000 & 2.50 & .9938 & 4,472 \\
4,500 & 632.46 & 3,000 & 2.37 & .9911 & 4,459 \\
4,500 & 700 & 3,000 & 2.14 & .9838 & 4,427 \\
4,500 & 800 & 3,000 & 1.88 & .9699 & 4,364 \\
4,500 & 900 & 3,000 & 1.67 & .9525 & 4,286 \\
4,500 & 1,000 & 3,000 & 1.50 & .9332 & 4,199 \\
\hline
\end{tabular}

Table 2 Monetary equivalents

\begin{tabular}{lcccccc}
\hline$E(X)$ & $S(X)$ & $I$ (interest) & Cost of debt & $Z \beta$ & Probability & IPR $\$$ \\
\hline 4,500 & 632.46 & .01 & 750 & 5.93 & 1.0 & $4,500.00$ \\
4,500 & 632.46 & .02 & 1,500 & 4.74 & 1.0 & $4,500.00$ \\
4,500 & 632.46 & .03 & 2,250 & 3.56 & .9999 & $4,499.95$ \\
4,500 & 632.46 & .04 & 3,000 & 2.37 & .9911 & $4,459.95$ \\
4,500 & 632.46 & .05 & 3,750 & 1.19 & .8830 & $3,973.50$ \\
4,500 & 632.46 & .06 & 4,500 & 0.00 & .5000 & $2,250.00$ \\
4,500 & 632.46 & .07 & 5,250 & -1.10 & .1170 & 526.50 \\
4,500 & 632.46 & .08 & 6,000 & -2.37 & .0089 & 40.05 \\
\hline
\end{tabular}

Table 3 Monetary equivalent vs. capital structure

\begin{tabular}{lcccccc}
\hline Debt & $\begin{array}{c}\text { Debt equity } \\
\text { ratio }\end{array}$ & $\begin{array}{c}\text { Cost of } \\
\text { debt }\end{array}$ & Net profit & $Z \beta$ & $\begin{array}{c}\text { Probability } \\
\text { [normal (CDF)] }\end{array}$ & IPR \$ \\
\hline 55,000 & 0.28 & 2,200 & 2,300 & 3.64 & 0.99986 & $4,499.37$ \\
65,000 & 0.33 & 2,600 & 1,900 & 3.00 & 0.99865 & $4,493.93$ \\
75,000 & 0.38 & 3,000 & 1,500 & 2.37 & 0.99110 & $4,459.95$ \\
85,000 & 0.43 & 3,400 & 1,100 & 1.74 & 0.95910 & $4,315.95$ \\
95,000 & 0.48 & 3,800 & 700 & 1.11 & 0.88650 & $3,989.25$ \\
\hline
\end{tabular}

Table 2 yields the results when the cost of debt (the interest rate) increases, and again the IPR \$ will change in the negative direction. The decrease obviously is what one would expect from the interest rate increase. Finally, Table 3 illustrates the changes associated 
with the change in the debt/equity ratio. Estimating the value of IPR $\$$ is subject to changes in the variables associated with sound decision making and do effect analysts' forecasts, which aid management in decision analysis and sound data analysis with full information.

\section{Conclusions}

In conclusion, problems associated with analysts' forecasts of earnings, cash flow, and rates of return continue often because intangible assets are either not estimated properly or not even considered in the forecasting process at all. No matter that rules of accrual accounting are utilised or not utilised; error may exist in analysts' forecast even when one properly uses forecast methods. If the influence of intangible assets often referred to as intellectual property continue to grow and not be reported in financial statements, the error associated with the growth in these assets will correlate with the magnitude of errors in forecast. Even testing the finding that use of accruals will improve analysts' forecast accuracy is insufficient in recognising that increases in cash flow is related to the growth and use of IP.

The purpose of this study is to employ estimation in financial accounting to permit analysis and financial reporting and analysts' forecasts, because to recognise the value of IPR (intellectual capital and other intangible assets) which are often the major source of error in prediction of rates of return, risk as measured by the CAPM and other variables that are part of the problems associated with M\&A and other business combinations including abandonment. Ignoring the estimation of non-monetary variables is a systematic error in analysts' forecasts of rates of return and earnings, which have a long history in financial reporting. The principles of matching and realisation (shown to be the same problem in previous literature) created problems of the recognition of revenues and matching of costs with revenues. Timing and allocation problems are the same principle, and only elementary accounting textbooks would present them as different. We should note that the allocation problems in financial accounting are already known, as noted in the review by others and also offer solutions to reporting problems associated with methods of estimation application in financial accounting.

Note also that overestimation of cash flow resulting in the overestimate of income inflates rates of return for firms. Rates of return are still used for making decisions concerning investments in and the abandonments of projects. Analysts' forecasts are particularly important in decisions concerning portfolio management as well.

\section{References}

Barnea, A. and Sadan, S. (1974) 'On the decomposition of the estimation problem in financial accounting', Journal of Accounting Research, Vol. 12, No. 1, pp.197-203.

Beneish, M.D., Lee, C.M.C. and Nichols, D.C. (2013) 'Earning manipulation and expected returns', Financial Analysts Journal, Vol. 69, No. 2, pp.57-82.

Bierman Jr., H. (1971) 'Discounted cash flows, price level adjustments and expectations', The Accounting Review, Vol. 46, No. 4, pp.693-699.

Brandon, C. and Jarrett, J.E. (1974) 'Accuracy of financial forecasts', Financial Review. Vol. 9, No. 1, pp.29-45. 
Brief, R. and Owen, J. (1968) 'A least squares allocation model', Journal of Accounting Research, Vol. 6, No. 2, pp.193-199.

Brief, R. and Owen, J. (1969) 'A note on earnings risk and the coefficient of variation', Journal of Finance, Vol. 24, No. 4, pp.901-904.

Brief, R. and Owen, J. (1970) 'The estimation problem in financial accounting', Journal of Accounting Research, Vol. 8, pp.167-177.

Brief, R. (1977) 'A note on the inclusion of earnings risk in measures of return: a reply', Journal of Finance, Vol. 32, No. 4, p.1367.

Clement, M.B. (1999) 'Analyst forecast accuracy: do ability, resources, and portfolio complexity matter?', Journal of Accounting and Economics, Vol. 27, No. 3, pp.285-303.

Dechow, P.M. and Schrand, C.M. (2004) Earnings Quality, Research Foundation of CFA Institute, Charlottesville, VA.

Dechow, P.M. (1994) 'Accounting earnings and cash flows as measures of firm performance: the role of accounting accruals', Journal of Accounting \& Economics, Vol. 18, No. 1, pp.3-42.

Gordon, M. and Halpern, A. (1974) 'Cost of capital for a division of a firm', Journal of Finance, Vol. 29, No. 4, pp.1153-1163.

Groysberg, B., Healy, P., Nohria, N. and Serafeim, G. (2011) 'What factors drive analyst forecasts?', Financial Analysts Journal, Vol. 67, No. 4, pp.18-29.

Gu, F. and Wang, W. (2005) 'Intangible assets, information complexity and analysts' earnings forecasts', Journal of Business Finance and Accounting, Vol. 32, Nos. 9-10, pp.1673-1702.

$\mathrm{Gu}, \mathrm{Z}$. and Wu, J.S. (2003) 'Earnings skewness and analyst forecast bias', Journal of Accounting and Economics, Vol. 35, No. 1, pp.5-29.

Hagendorff, J., Hernando, I., Nieto, M.J. and Wall, L.D. (2012) 'What do premiums paid for bank M\&A's reflect? The case of the European Union', Journal of Banking \& Finance, Vol. 36, No. 3, pp.749-759.

Jarrett, J.E. and Khumawala, S. (1987) 'A study of forecast error and covariant time series to improve forecasting for financial decision making', Managerial Finance, Vol. 13, No. 2, pp. $20-24$.

Jarrett, J.E. (1971) 'The principles of matching and realization as estimation problems', Journal of Accounting Research, Vol. 9, No. 2, pp.378-382.

Jarrett, J.E. (1974) 'Bias in adjusting asset values for changes in the price level: an application of estimation theory', Journal of Accounting Research, Vol. 12, No. 1, pp.63-66.

Jarrett, J.E. (1978) 'Estimating the cost of capital for a division of a firm, and the allocation problem in accounting', Journal of Business Finance and Accounting, Vol. 5, No. 3, pp.39-47.

Jarrett, J.E. (1983) 'The rate of return from interim financial reports', Journal of Business Finance and Accounting, Vol. 10, No. 2, pp.289-294.

Jarrett, J.E. (1992) 'An economical method for correcting forecasting error', American Journal of Business, Vol. 7, pp.55-58, DOI: 10.1108/19355181199200017.

Jarrett, J.E. (2016) 'The problems of accounting reporting false information and estimation', Intellectual Property Rights, Vol. 4, S1:007, DOI: 10.4172/2375-4516.1000S1-007.

Jarrett, J.E (2017a) 'Intellectual property valuation and accounting', Intellectual Property Rights, Vol. 5, No. 1, p.1, DOI: 10.4172/2375-4516.100081.

Jarrett, J.E. (2017b) 'Intellectual property and the role of estimation in financial accounting and mergers and acquisitions', SF Journal of Intellectual Property Rights, Vol. 1, No. 1, pp.1-8.

Jin, K., Shan, Y. and Taylor, S. (2015) 'Matching between revenues and expenses and the adoption of International Financial Reporting Standards', Pacific-Basin Finance Journal, Vol. 35A, No. 1, pp.90-107.

Jung, B., Shane, F. and Yang, Y. (2012) 'Do financial analysts' long-term growth forecasts matter? Evidence from stock recommendations and career outcomes', Journal of Accounting and Economics, Vol. 53, Nos. 1-2, pp.55-76. 
Kimouche, B. and Rouabbi, A. (2016) 'The impact of intangibles on the value relevance of accounting information: evidence from French companies', Intellectual Capital, Vol. 12, No. 2, pp.506-529.

Lambert, D., Matolcsy, Z. and Wyatt, A. (2015) 'Analysts' earnings forecasts and technological conditions in the firm's investment environment', Journal of Contemporary Accounting and Economics, Vol. 11, No. 2, pp.1-46.

Matolcsy, Z. and Wyatt, A. (2006) 'Capitalized intangibles and financial analysis', Accounting and Finance, Vol. 46, pp.457-479, DOI: 10.1111/j.1467-629x2006.00177x.

Pappas, J.L. (1977) 'A note on the inclusions of earnings risk in measures of return: a comment', Journal of Finance, Vol. 32, No. 4, pp.1363-1366.

Ramnath, S., Rock, S. and Shane, P.B. (2008) 'The financial analyst forecasting literature: a taxonomy with suggestions for further research', International Journal of Forecasting, Vol. 24, No. 1, pp.34-75.

Roberts, C. and Roberts, E. (1970) 'Exact determination of earnings risk by the coefficient of variation', Journal of Finance, Vol. 25, pp.1161-1165.

Thornton, G. (2013) Intangible Assets in Business Combinations: Identifying and Valuing Intangibles under IFRS 3, Grant Thornton International, Chicago.

White, G.I., Sandhi, A.C. and Fried, D. (1994) The Analysis and Uses of Financial Statements, 3rd ed., Wiley, New York.

World Trade Organization (WTO) 2016 What Are Intellectual Property Rights?, World Trade Organization, Geneva. 